Corrigendum

\title{
Corrigendum to "Holocene reactivations of catastrophic complex flow-like landslides in the Flysch Carpathians (Czech Republic/Slovakia)" [Quat. Res. 80 (2013) 33-46]
}

\author{
Tomáš Pánek ${ }^{\mathrm{a}, *}$, Veronika Smolková a , Jan Hradecký a , Ivo Baroň ${ }^{\mathrm{b}, 1}$, Karel Šilhán ${ }^{\mathrm{a}}$ \\ a Department of Physical Geography and Geoecology, Faculty of Science, University of Ostrava, Chittussiho 10, 71000 Ostrava, Czech Republic \\ b Czech Geological Survey, Brno branch, Leitnerova 22, 65869 Brno, Czech Republic
}

The authors regret that the caption related to the normalised probability density curve of the Czech and Polish landslide events (part of Fig. 8, page 44) contains an incomplete list of citations. The correct caption of this curve is as follows:

(2) normalised probability density curve of the Czech and Polish landslide events, 85 dates (Alexandrowicz, 1993; Alexandrowicz and Alexandrowicz, 1999; Baroň, 2007; Hradecký et al., 2004, 2007; Margielewski, 1997, 1998, 2001, 2003, 2006a; Margielewski and Kovalyukh, 2003; Smolková et al., 2008; Margielewski et al., 2010, 2011 plus our unpublished ages of five landslides from the Czech part of the Outer Western Carpathians; see Supplementary Table 1).

Supplementary data to this article can be found online at http://dx. doi.org/10.1016/j.yqres.2013.10.013.

\section{References}

Alexandrowicz, S.W., 1993. Late Quaternary landslides at eastern periphery of the National Park of the Pieniny Mountains, Carpathians, Poland. Studia Geologica Polonica 192, 209-225.

Alexandrowicz, S.W., Alexandrowicz, Z., 1999. Recurrent Holocene landslides: a case study of the Krynica landslide in the Polish Carpathians. The Holocene 9, 91-99.

Baroň, I., 2007. Results of radiocarbon dating of deep-seated landslides in the area of Vsetín and Frýdek-Místek districts. Geologické výzkumy na Moravě a ve Slezsku 14, 10-12 (in Czech with English abstract).

Hradecký, J., Pánek, T., Břízová, E., 2004. Contribution to the geomorphology and the age of the selected slope deformations in the area of Slezské Beskydy Mts. and Jablunkovská Brázda Furrow. Geografie 109, 289-303 (in Czech).
Hradecký, J., Pánek, T., Klimová, R., 2007. Landslide complex in the northern part of the Silesian Beskydy Mountains (Czech Republic). Landslides 4, 53-62.

Margielewski, W., 1997. Dated landslides of the Jaworzyna Krynicka Range (Outer Carpathians) and their relation to climatic phases of the Holocene. Annales Societatis Geologorum Poloniae 67, 83-92.

Margielewski, W., 1998. Landslide phases in the Polish Outer Carpathians, and their relation to climatic changes in the Late Glacial and the Holocene. Quaternary Studies in Poland 15, 37-53.

Margielewski, W., 2001. Late Glacial and Holocene climatic changes registered in forms and deposits of the Klaklowo landslide (Beskid Średni Range, Outer Carpathians). Studia Geomorphologica Carpatho-Balcanica 35, 63-79.

Margielewski, W., 2003. Late Glacial-Holocene palaeoenvironmental changes in the Western Carpathians: case studies of landslide forms and deposits. Folia Ouaternaria 74, 1-96.

Margielewski, W., Kovalyukh, N.N., 2003. Neoholocene climatic changes recorded in landslide's peat bog on Mount Ćwilin (Beskid Wyspowy Range, Outer Carpathians). Studia Geomorphologica Carpatho-Balcanica 37, 59-76.

Margielewski, W., 2006a. Records of the Late Glacial-Holocene palaeoenvironmental changes in landslide forms and deposits of the Beskid Makowski and Beskid Wyspowy Mts. Area (Polish Outer Carpathians). Folia Quaternaria 76, 1-149.

Margielewski, W., Krąpiec, M., Valde-Nowak, P., Zernitskaya, V., 2010. A Neolithic yew bow in the Polish Carpathians: evidence of the impact of human activity on mountainous palaeoenvironment from the Kamiennik landslide peat bog. Catena 80, 141-153.

Margielewski, W., Kołaczek, P., Michzcyński, A., Obidowicz, A., Pazdur, A., 2011. Record of the meso-and neoholocene palaeoenvironmental changes in the Jesionowa landslide peat bog (Beskid Sądecki Mts. Polish Outer Carpathians). Geochronometria 38, $138-154$.

Smolková, V., Pánek, T., Hradecký, J., 2008. Fossil landslide-dammed lake in the Babínek valley (Vsetínské vrchy Hills): contribution to understanding the Holocene relief development in the flysch Carpathians. Geologické výzkumy na Moravě a ve Slezsku $\mathrm{v}$ roce 2007, 15, pp. 41-43 (in Czech).

1 Recent address: Geological Survey of Austria, Neulinggasse 38, 1030 Vienna, Austria. 